\title{
The Soft Power of the State as a Dialectic of Contemporary Dependencies in the International Arena
}

\author{
Denys Svyrydenko \\ Doctor of Philosophical Sciences, Associate Professor, Guangdong University of \\ Petrochemical Technology (Maoming, China) \\ E-mail: denis_sviridenko@ukr.net \\ https://orcid.org/0000-0001-6126-1747

\section{Wiktor Możgin} \\ Ph.D. Student, Jagiellonian University in Kraków (Kraków, Poland) \\ E-mail: wiktor.mozgin@doctoral.uj.edu.pl \\ https://orcid.org/0000-0001-5744-8103
}

Svyrydenko, Denys and Wiktor Możgin (2019) The Soft Power of the State as a Dialectic of Contemporary Dependencies in the International Arena. Ukrainian Policymaker, Volume 5, 89-97. https://doi.org/10.29202/up/5/10

Dialectic is a concept that means the ability to argue leading to confirmation or questioning the thesis. Derived from ancient time, various currents of understanding the concept of dialectics in the modern world are subject to redefinition and constitute the basis for the functioning of the sphere of interactions in the international arena. Today's discourse on the relationship between various entities boils down to the claim that hard power began to give way to soft power. The implementation of dialectic assumptions in the functional space of the soft power of the state makes it possible to conclude that, today, entities on the international stage, pursuing their particular interests, do not always use a narrative that is consistent with reality. Therefore, an important aspect of mutual interaction is making an objective analysis of phenomena and events that form the basis for establishing various types of relationships on the world stage.

Keywords: dialectics, state pragmatism, soft power, mutual relations, international relations, raison d'état, challenges of the modern world

Received: July 26, 2019; accepted: September 1, 2019

(C) Svyrydenko, Denys, 2019

(C) Możgin, Wiktor, 2019 


\section{Introduction}

The Peace of Westphalia, concluded in 1648, ending the Thirty Years' War, has made a mark on history as an event not only heralding a new order in Europe, but also as a phenomenon about the emergence of a formally non-existing international system. The factor that makes it possible to claim that at that time a new matter of relations between particular entities on the international arena began to shape is the process of formalization of these relations, which until now were based on the connections of heterogeneous feudal actors. The Westphalian agreement initiated the tendency to consolidate sovereignty, which was based on the monopolization of means of violence and sole control over foreign policy instruments. In the mid-seventeenth century to have these prerogatives testified about the subjectivity on the world arena (Gałganek, 2008: 24). International relations have since gained theoretical orientation and coherence, says Benno Teschke. This became possible through the process of diffusion and convergence of trends characteristic of various paradigms and disciplines (Teschke, 2003: 2-4).

The theoretical assumptions of the science of international relations in the late wave period boil down primarily to the issue of ensuring the security of the state, increasing its power and position in the international arena. The factor that implements these principles is the foreign policy pursued by individual countries. In addition, the theoretical and practical premises of external policy have not fundamentally changed since the 17 th century, since the goal of each entity is still to ensure security and achieve the best position in relation to others. However, the means, tools and methods of their implementation have changed. This is primarily due to the dynamics of the international environment, which is constantly changing under the influence of continuous technological and information development (Zięba, 2005: 48-55).

In the post-westphalian world, the change in international conditions has contributed to the redefinition of the principles and methods regulating the functioning of this sphere. The emergence of new entities, and therefore new formal and institutional challenges, is today one of the directions in which the space of international influence is developing. The implication of this state of affairs is the desire of states to expand the scope of their means, tools and methods to effectively implement foreign policy.

Pragmatism of international conduct in the modern world boils down to a tendency when hard power begins to give way to soft power. In this context, the main problem boils down to the statement that the world, in fear of total destruction, taking into account every aspect of the functioning of the state, seeks to implement the assumptions of its foreign policy by using means directed at dialogue, persuasion and agreement (Podobas, 2013: 105-106). Certainly these are not the only means used by states, because hard power is still present in the rhetoric of the modern world, taking on the face of various types of military conflicts. Despite the perspective of wars waged in various corners of the globe, the contemporary tendency to interact internationally boils down to negotiation processes and mutual dialogue. The asymmetry of conflicts in today's world is an important aspect that should be taken into account by the governments of all countries and institutions with legitimacy of international subjectivity (Szczurek, 2014: 13-14).

The multi-faceted and multi-subjectivity of phenomena in today's world provides the basis for treating hard power as an insufficient tool for implementing policy, because in an environment of mutual dependencies and interactions, subjects of international relations basically base their actions on methods and tools having a dialectical character (Svyrydenko \& Yatsenko, 2018). Therefore, the purpose of this work is to indicate vectors 
of development of contemporary international relations through the implementation of soft power dialectics in the system of mutual interactions as an effective tool for foreign policy implementation of individual entities. Illustrating in these context tendencies often based on overbearing, particular actions of states constituting the essence of constructive dialogue on the world stage.

\section{Soft power as a tool for implementing state policy on the international stage}

In the conditions of systemic, ideological and axiological changes that took place in the early 1990s, the concept of soft power appeared. Its creator was the American researcher in the field of international relations, Joseph S. Nye, who in his work Bound to Lead: The Changing Nature of American Power formulated the concept of soft power, in short, consisting of the ability to persuade entities operating on the world stage to follow our desires and assumptions (Nye, 1991: 14-17). This assumption boils down to the postulate that soft power is the ability of the state to attract others by changing their preferences in such a way that they act in the interest of the state, which thanks to its "attractiveness" draws attention in the system of interactions on the global arena (Fijałkowski \& Polus, 2014: 255-257).

The "attractiveness" of the state is nothing more than the ability to attract various entities to the sphere of their influence. The level of political mobilization, evaluation of the level of development of democracy, etc. directly influences on the "attractiveness" level (Iskhakova, 2018; Możgin, 2018). Having these abilities testifies first of all to the power of a given country. The concept of power in this work is implemented in the context of the concept of soft power. The classic approach to this phenomenon refers to the real military (material) strength of the state and is included in the current paradigm of the realistic, characteristic of the sphere of hard power. Despite such inclinations, it is worth noting that the issue of power refers primarily to the multi-faceted nature of the issue and is interpreted in accordance with the assumptions of the policy pursued by a particular country. Hence, we can talk about the semantic dualism of the concept of power, because on the one hand we can treat it in terms of military (material) strength, and on the other as an axiological and cultural (immaterial) tool. The barrier to the introduction of a clear definition of the concept of power is its complexity and multifaceted. There are several aspects of understanding this concept, among which it is worth mentioning the power understood as the ability to resolve conflicts, power as the ability to exercise control over the setting of rules applicable to entities of mutual interaction and power as a predisposition to formulate and export cultural and ideological postulates addressed to a wider audience (Fijałkowski \& Polus, 2014: 260-261).

The first understanding of the concept of power is part of the context of realistic theory of international relations. The materialistic nature of this approach often treats power as a country's military capabilities that are objectively measurable (e.g. army size, status of a nuclear state, number of weapon units) (Dybczyński, 2005: 647-649). In this context, one should not ignore the country's natural resources, which in relation to other entities testify to its "attractiveness" and testify to its functional abilities - this is, among others predisposition to have the right amount of energy raw materials along with processing infrastructure that ensures energetic independence, and thus creates the assets of a given entity, as well as having the right mineral resources used in creating high-tech machines controlling production and processing processes (Pysar et al., 2018). 
The second and third shot comes down to the context of soft power. Despite constructive discrepancies, which clarify the differences in these approaches, it should be remembered that the border between different understandings of the concept of power is fluid and it often happens that there is a fusion of some concepts that are characteristic of different theoretical approaches. Therefore, when talking about the power of the state or another entity on the international arena (do not forget the fact of the existence and influence of multinational corporations, whose resources often exceed the capabilities of certain countries), one should remember about semantic dualism that boils down to a distinction between hard power and soft power. However, the legitimacy of the use of these tools by individual countries as part of their policy implementation boils down to the common goal of pragmatism in achieving the tasks outlined.

Despite the statements regarding hard power, this work boils down to formulating the main directions of the influence of soft power on the process of mutual interactions on the international arena. The means of expressing the soft power of the state are primarily culture, which influences the attractiveness of the state through the interest of other entities in cultural heritage, tradition and religion; political values that are manifested by sketching and observing the appropriate axiological framework, which in the modern world most often boils down to having a democratic system based on respect for human rights and dignity (but not all the countries that we can now enlist as powers that combine the aspects of hard and soft power, follow democratic and law-abiding rules; it is a utopian system that Western countries are trying to implement in the modern world); and foreign policy in the broad sense, the exemplification of which is diplomatic opportunity to negotiate internationally.

In the context of this article, it should be assumed that the sphere in which the interactions of entities on the world stage occurs is of a dialectical nature. This is primarily due to the very definition of dialectic, because in the classic approach this concept means on the one hand a way of intellectual cognition that transcends formal logical relationships and is directed at revealing the dynamic nature of your subject, on the other — the art of argumentation that leads to confirmation or question the thesis (Adler, 2001: 21-24). The dialectical nature of contemporary relations between countries fits into the eristic stream of reasoning for this concept, when we deal with dialectics as the art of applying in the discussion the rules leading to the superiority of their arguments, which are not necessarily always a coherent and logical whole (Arthur, 1998: 450-452). Within this trend, two approaches have emerged that treated dialectics on the one hand in a rhetorical way, describing it as pursuing a goal by showing truthfulness, and on the other, pragmatic, meaning achieving the goal even using false arguments. Therefore, by implementing the concept of dialectics in the context of contemporary interactions on the international arena, we have an excellent picture of the mechanisms and principles regulating this sphere of subjective activity. The thing concerns above all such phenomena as unsustainable technological and economic development, sociocultural stratification and the information boom, one of the determinants of which is the increasingly frequent use of the so-called fake news. These factors belong to the constructive elements in which the soft power of each country finds its reflection. The economic, political and cultural predispositions of individual entities on the international stage testify to his ability to participate in international processes. 


\section{Mutual interaction of entities on the international arena}

From the perspective of several years, it can be said that the change in the balance of power in the international arena, which took place at the end of the twentieth century, was just a moment of redefinition of the basic mechanisms guiding global politics. Bipolar world, in which the United States and the Soviet Union played a dominant role today has been replaced by a multi-vector and multi-faceted world. Nowadays, the complexity of the balance of power in the global arena consists in the formation of many centers of regional interaction. On the one hand, they are regional powers such as China, Russia, Iran, Brazil, India and South Africa, and on the other, they are international corporations, which often cover the whole world - they include entities suc h as Google, Amazon or Apple. Francis Fukuyama in his book The End of History and The Last Man announced his famous thesis that the collapse of the bipolar balance of power heralded the end of rivalry between powers and permanent development, the center of which would be the United States (Fukuyama, 2006: 17-21).

The perspective of a unipolar world could not survive too long, because the American state was not able to stand the influence of other entities that were directed at dismantling the existing norms and principles. Fareed Zakaria, an American journalist and researcher in the field of international relations, announced the thesis that the beginning of the $21^{\text {st }}$ century is the end of the hegemony of the United States. At the same time, he pointed to the importance of the non-Western world, because many factors, both economic, cultural and social, pointed to the increase in the "attractiveness" of countries such as China, India, Iran and Brazil (Zakaria, 2009: 81-85). Not only Fareed Zakaria pointed to a departure from world unipolarity and the formation of a multipolar world, because another American researcher Robert Kagan referred in his works to the tendency of formation of regional powers in different parts of the world (Kagan, 2009: 37-41).

In this context, one fundamental question comes to mind, namely, what does it mean to be a regional power? The answer comes down to finding the "attractiveness" of a given entity, taking into account its predispositions, which include hard power and soft power. Despite this, keeping the direction of the considerations of this work, only the sphere of soft power of entities operating on the global arena will be taken into account. Joseph Nye pointed to the permanent dynamics of the sphere of international influences, arguing that the essence of the international system is to strive for balance consisting in building a counterweight to dominant powers (Nye, 2002: 2-4). Therefore, we return once again to the concept of the "attractiveness" of the subject, which affects the ability to create various types of relationships between him and another subject in order to realize the particular interests that make up the raison d'état of each of them. Soft power dialectics are manifested here in the formal and informal predispositions of the subject. Formality in this context consists in the institutional integration of various entities, when specific issues are agreed at the level of government negotiations - among others security, energy supplies, or trade agreements. Even family policy of the national states can be a matter negotiation in the face of globalization challenges (Tulowecki \& Svyrydenko, 2018: 92-94). In turn, the informal scope of relationships is based on the cultural "attractiveness" manifested in exporting patterns and values by a potentially stronger and more attractive state to other entities, which results in the assimilation and unification of codes that the society adopting these patterns and values begins to use (e.g. phenomenon of "mcdonaldization" of society) (Ritzer, 2004: 31-33). 
Joseph Nye's soft power concept has become a source of inspiration for other researchers in the sphere of international relations. In this context, a slightly different approach to this issue was presented by the Russian diplomat and analyst Konstantin Kosachev. According to his claim, soft power is not only the ability to present the sphere of its axiological advantages, but also to respect the values of others. In addition, this concept is equated with the subject's ability to coexist with others without the necessity of assimilation and to create conditions and rules affecting the development and survival of the cultural sphere of entities with whom we establish relationships (Kosachev, 2012). According to Konstantin Kosachev, who was primarily involved in analyzing Russia's position in the international arena, the authorities in the Kremlin have not developed their own, unique only to the Russian state, soft power tools that would shape in this respect a model that is equivalent to the Chinese or American model of using soft power mechanisms to other players on the world stage. Both Chinese and American models are directed at exporting values and economic prerogatives that allow other entities to provide their own economic, energy and military security. There are many examples that exemplify this state of affairs, because China through its economic expansionism builds a strong base in the form of alliances with European, African and South American countries, based on services in the sphere of economy and the latest technologies (Huang, 2008: 23-25). In turn, the United States using a similar model is trying to gain support on the European continent and in Asia. This is mainly due to the strategic geopolitical plans of the American government, which cannot be reconciled with the fact that the United States is not a hegemon in the international arena today (Zakaria, 2009: 47-50).

There is no doubt that in the modern world, both China and the United States have shaped structured systems of influence on countries of their interest. The "attractiveness" of these countries on the international stage is beyond doubt. Interesting in this context is the position of Russia, which after the collapse of the Soviet Union was able to rebuild its power and may become not a global, but at least a regional power. Referring again to the achievements of Konstantin Kosachev, it is worth noting that the Russian state's narrative of soft power is based on three pillars: cooperation, security and sovereignty (Pacak, 2012: 196). The narrative used by this Russian researcher boils down to the claim that Russia allowed the former Soviet Union countries to form their own states without any resistance. In addition, Konstantin Kosachev claims that the rooting of Soviet culture, religion and identity is so strong in the Länder (federal states) that they form an independent political and social creation that could not exist without modern Russia (Kosaczew, 2012).

Analyzing this message of one of the leading Russian diplomats and experts in international relations, we are again returning to the theoretical sphere of dialectics, which indicates that any narrative that brings a given subject closer to achieving the intended goal is justified. Given the actual state of affairs, because it is about the war in eastern Ukraine and the unsanctioned annexation of the Crimean peninsula in which the Russian state is involved, the only conclusion is that, guided by the "Machiavellian" principle that "every goal justifies the means," Russia today seeks to rebuild its spheres of influence by using not always fair means and mechanisms. Russian soft power is focused on "close abroad" and is implemented through the use of the now outdated methods of Marxist dialectics, which through its pragmatism does not take into account the conditions and principles in the modern world.

The United States, China, the Russian Federation and many other regional powers are today trying to use their own strengths proving their strength and power. Despite this, contemporary actors of the world political scene are focused on cooperation and strive for 
sustainable development and technological and information progress. Therefore, the analysis of the interactions of entities on the international arena is an important aspect influencing the development of science focusing its attention on the theoretical assumptions constituting the essence of relations between various entities.

\section{Conclusions}

The interaction of various entities on the international arena nowadays boils down to a pattern that consists in the pragmatic nature of these relationships. Today it is important to achieve the goal and it often happens that entities use their "attractiveness" manifested in the form of political (democratic system), economic (having developed economies based on modern information technologies), energy (ability to export energy resources) and cultural (linguistic and religious proximity).

The dialectical nature of the sphere of interaction on the world stage further emphasizes the legitimacy of the statement that in the modern world soft power takes on greater significance than hard power. The pragmatic current of understanding dialectics defines it as a tool for winning disputes even with faulty and false arguments (Ziomek, 2000: 23-24). Derived from sophists, this trend played an important role in the further development of dialectics as a tool for achieving intended goals. Arthur Schopenhauer in his Eristic referred to a narrative arising from the concept of Niccolò Machiavelli's power, which defined dialectics as an art of discussing aimed at maintaining appearances (Siemek, 1982: 13-16). The notion of dialectic in the Marxist-Leninist approach emerged in the same trend, which played an important role in shaping the soft power of contemporary states, especially the Russian Federation. Vladimir Lenin in his reflections on dialectics pointed out, on the one hand, that everything is an intrinsically diverse whole, on the other, stressed that the relations of each thing are not only many times diverse, but also general and universal, because the fact that everything is associated with everyone (Lenin, 1956: 194-195).

Today, analyzing the narrative of many countries, directed outside, aimed at influencing other entities, one can see the difference between the actual state and the one that is presented during various types of negotiations, meetings and contacts that occur internationally. This article was intended to signal the emerging and increasingly used tendency to use soft power tools in the implementation of the policy of various entities on the world stage. Sidney Hook in his considerations argued that a factor that is objectively present in things and processes is a contradiction. The contradiction, which is the basis of all laws of dialectics, which perfectly captures the essence of contemporary interactions in the world. Since the days of Aristotle, it is generally accepted in the theory of logic that statements, judgments or sentences are contradictory, not objects or events (Hook, 1958: 185-186).

Therefore, in this context, an important is the objective analysis of the narrative guided by the players of global games in the sphere of public discourse. Soft power, which demonstrates the ability of these entities to draw other, less "attractive" entities into their influence, is today an indispensable tool in implementing the strategic policies of various entities. That is why it is extremely important to pay attention to processes directed at the interaction of entities on the world stage, because each of them is based on a particular interest, constituting the raison d'état, which will not always have positive effects on the global community. The negative consequences of such interactions may be various kinds of wars, conflicts and social tensions, leading to international instability. 


\section{References}

Adler, Mortimer (2001) Dialectic, New York/London.

Arthur, Christopher (1998) Systematic Dialectic.Science \& Society, vol. 62, No. 3, 447-459.

Dybczyński, Andrzej (2005) Teoria powstawania sojuszy i realistyczna wizja środowiska międzynarodowego, [in:] Porządek międzynarodowy u progu XXI wieku, ed. by R. Kuźniar, Warszawa, 644-656.

Fijałkowski, Łukasz and Andrzej Polus (2014) Krytyczne spojrzenie na pojęcie soft power Josepha S. Nye'a w stosunkach międzynarodowych, [in:] Stosunki międzynarodowe. Wokót zagadnień teoretycznych, ed. by K. Kącka, Toruń, 255-274.

Fukuyama, Francis (2006) The End of History and The Last Man, New York.

Gałganek, Andrzej (2008) Westfalia jako metafora genezy w nauce o stosunkach międzynarodowych, [in:] Późnowestfalski lad międzynarodowy, ed. by M. Pietraś and K. Marzęda, Lublin, 23-56.

Hook, Sidney (1958) Materializm dialektyczny a metoda naukowa. [in:] Filozofia amerykańska. Wybór rozpraw i szkiców historycznych, ed. by J. Krzywicki, Boston, 181-194.

Huang, Yasheng (2008) Capitalism with Chinese Characteristics: Entrepreneurship and the State, Cambridge.

Iskhakova, Nataliia (2018) Trust as a Factor of Political Mobilization of Society in the Conditions of Establishment of Democracy. Ukrainian Policymaker, Volume 3, 2018: 11-16. https://doi.org/10.29202/up/3/2

Kagan, Robert (2009) The Return of History and the End of Dreams, London.

Kosaczew, Konstantin (2012) The Specifics of Russian Soft Power, 2012. https://eng. globalaffairs.ru/number/The-Specifics-of-Russian-Soft-Power-15683

Lenin, Włodzimierz (1956) Zeszyty filozoficzne, Warszawa.

Morgenthau, Henry (2010) Polityka między narodami. Walka o potęgę i pokój, Warszawa.

Możgin, Wiktor (2018) Ukraine in a Geopolitical Game between the West and the Russian Federation. Ukrainian Policymaker, Vol. 3, 36-42. https://doi.org/10.29202/up/3/5

Nye, S. Joseph (1991) Bound to Lead: The Changing Nature Of American Power, New York.

Nye, S. Joseph (2002) The Paradox of American Power: Why the World' Only Superpower Can't Go It Alone, Oxford.

Pacak, Paulina (2012) ,, Soft power” jako środek realizacji celów polityki zagranicznej państwa w systemie postwestwalskim, [in:] Poziomy analizy stosunków międzynarodowych, ed. by E. Haliżak and M. Pietraś, Lublin, 193-207.

Podobas, Izabela (2013) Sztuka dyplomacji czyli przełamywanie stereotypów i barier kulturowych w negocjacjach międzynarodowych, [in:] Dynamika współczesnych stosunków międzynarodowych, ed. by W. Kostecki, Warszawa, 103-123.

Pysar, Nadiya, Viktoriya Dergachova, Denys Svyrydenko, and Olga Kyvliuk (2018) Strategies for development of Ukrainian energy market under conditions of geopolitical challenges. Naukovyi Visnyk Natsionalnoho Hirnychoho Universytetu, Issue 5: 148154. https://doi.org/10.29202/nvngu/2018-5/20

Ritzer, Georg (2004) Klasyczna teoria socjologiczna, Poznań.

Siemek, Marek (1982) Filozofia, dialektyka, rzeczywistość, Warszawa.

Svyrydenko, Denys, and OlenaYatsenko (2018) Dialectics of Nominal and Real Power in the Ukrainian and World Politics. Ukrainian Policymaker, Vol. 2, 33-40. https://doi. org/10.29202/up/2/5 
The Soft Power of the State as a Dialectic of Contemporary Dependencies in the International Arena by Denys Svyrydenko and Wiktor Możgin

Szczurek, Tadeusz (2013) Asymetria w środowisku bezpieczeństwa, [in:] Asymetryczne zagrożenia bezpieczeństwa narodowego z XXI wieku, ed. by T. Szczurek, Warszawa, 11-23.

Teschke, Benno (2003) The Myth of 1648. Class, Geopolitics and the Making of Modern International Relations, London.

Tulowecki, Dariusz, and Denys Svyrydenko (2018)Family Policy of the State as a Response to Social Security Threats. Future Human Image, Vol. 10: 92-102. https://doi. org/10.29202/fhi $/ 10 / 10$

Zakaria, Fareed (2009) Koniec hegemonii Ameryki, Warszawa.

Zięba, Ryszard (2005) Cele polityki zagranicznej państwa, [in:] Wstęp do teorii polityki zagranicznej państwa, ed. by R. Zięba, Toruń, 37-55.

Ziomek, Jerzy (2000) Retoryka opisowa, Wrocław. 